\title{
ACTIVITY CHARACTERISTICS OF SULFATE REDUCING BACTERIA AND FORMATION MECHANISM OF HYDROGEN SULFIDE
}

\author{
DENG, Q. ${ }^{1,2,3^{*}}-\mathrm{WU}, \mathrm{X}^{2}-\mathrm{WANG}, \mathrm{Y}^{2}-\mathrm{LIU}, \mathrm{M}^{1,2}$ \\ ${ }^{1}$ State Key Laboratory Cultivation Base for Gas Geology and Gas Control, Henan Polytechnic \\ University, 454003 Jiaozuo, P. R. China
}

${ }^{2}$ School of Safety Science and Engineering, Henan Polytechnic University 454003 Jiaozuo, P. R. China

${ }^{3}$ Collaborative Innovation Center of Coal Safety Production of Henan Province 454003 Jiaozuo, P. R. China

*Corresponding author

e-mail: dengqigen@hpu.edu.cn; phone: +86-391-398-6252; fax: +81-391-398-7881

(Received $31^{\text {st }}$ May 2018; accepted $13^{\text {th }}$ Sep 2018)

\begin{abstract}
Various anaerobic environments exist in the Earth's ecosystem, which can produce a great deal of organic matter each year. In anaerobic habitats, bacterial sulfate reduction may occur due to the action of sulfate-reducing bacteria. As a result, hydrogen sulfide $\left(\mathrm{H}_{2} \mathrm{~S}\right)$ is formed. This paper focuses on sulfatereducing bacteria and the revision of the activity characteristics of these bacteria in the reducing environment. It discusses the metabolic process of sulfate-reducing bacteria using sulphate and organosulfur compounds as sulfur source, the mechanism of bacterial sulfate reduction and $\mathrm{H}_{2} \mathrm{~S}$ formation mechanism. There are two main ways of $\mathrm{H}_{2} \mathrm{~S}$ formation in sulfate-reducing bacteria, the production of metabolic sulphate and the metabolic organo-sulfur compounds (mainly cysteine). The paper, combined with the activity characteristics of sulfate-reducing bacteria and the pathway of metabolic formation of $\mathrm{H}_{2} \mathrm{~S}$, also discusses the circulation of sulfur in the environmental system of the Earth due to the action of sulfate-reducing bacteria, concerning the redox zone division in submarine sedimentary strata and landfills, the biogas formation phase of sulfate-reducing bacteria metabolism in sedimentary formations, and the bacterial sulfate reduction action in salt lakes (seawater) systems. Moreover, the production of hydrogen sulfide and the formation model of dolomite are both presented here. The findings support that sulfate-reducing bacteria are the most important biological source of $\mathrm{H}_{2} \mathrm{~S}$ production. The study of the physiological characteristics of sulfate-reducing bacteria and the formation mechanism of $\mathrm{H}_{2} \mathrm{~S}$ due to bacterial sulfate reduction can provide useful reference for the exploration of the laws of sulfur geochemical cycle and the rules of the ecological environment, which is essential for the protection of the natural environment and the restoration of polluted ecosystems, and can also provide a useful reference for the control of aerobic microorganisms.
\end{abstract}

Keywords: microorganism, hydrogen sulfide $\left(H_{2} S\right)$, bacterial sulfate reduction, formation mechanism

\section{Introduction}

Hydrogen sulfide is mostly the product of the decomposition of organic matter under the microorganisms' action, the action of bacterial sulfate reduction (BSR), or the chemical process byproducts (Deng, 2017). The sulfate-reducing bacteria absorbs sulfate without the participation of oxygen, obtains energy from the oxidation of organic compound and discharges $\mathrm{H}_{2} \mathrm{~S}$ produced by the reduction of sulfate, which metabolic process is defined as bacterial sulfate reduction (Machel, 2001; Orr, 1974). The gaseous pollutant of $\mathrm{H}_{2} \mathrm{~S}$ mainly comes from man-made pollution and natural pollution. Manmade pollution mainly includes exploitation of petroleum, coal-bed methane, shale gas 
etc, mining and non-ferrous metal smelting, low-temperature coking of coal, extraction of sulfur-containing substances, rubber, leather, dyes and other industrial production. Natural pollution often exists in many anaerobic environments in the Earth's ecosystems, such as underground pipeline, rice fields, industrial effluent, mud, swamps, lake bottom sediments, oil and gas wells, hot springs, landfills, and farm excretion, deposits and other venues (Martins et al., 2009).

The hazards of $\mathrm{H}_{2} \mathrm{~S}$ are mainly manifested in the following two aspects:

(1) Hazards to health. $\mathrm{H}_{2} \mathrm{~S}$, a polar molecule, is highly toxic and flammable. It is colorless, smelly and prone to explosion. A small amount of $\mathrm{H}_{2} \mathrm{~S}$ in high concentration inhaled can be fatal to a person in a short time (Wei et al., 2014; Deng et al., 2018). And $\mathrm{H}_{2} \mathrm{~S}$ in low concentration affects the eye, respiratory and central nervous system badly. The physiological effects of $\mathrm{H}_{2} \mathrm{~S}$ concentration and contact time on human body are shown in Figure 1 (Wei et al., 2014).

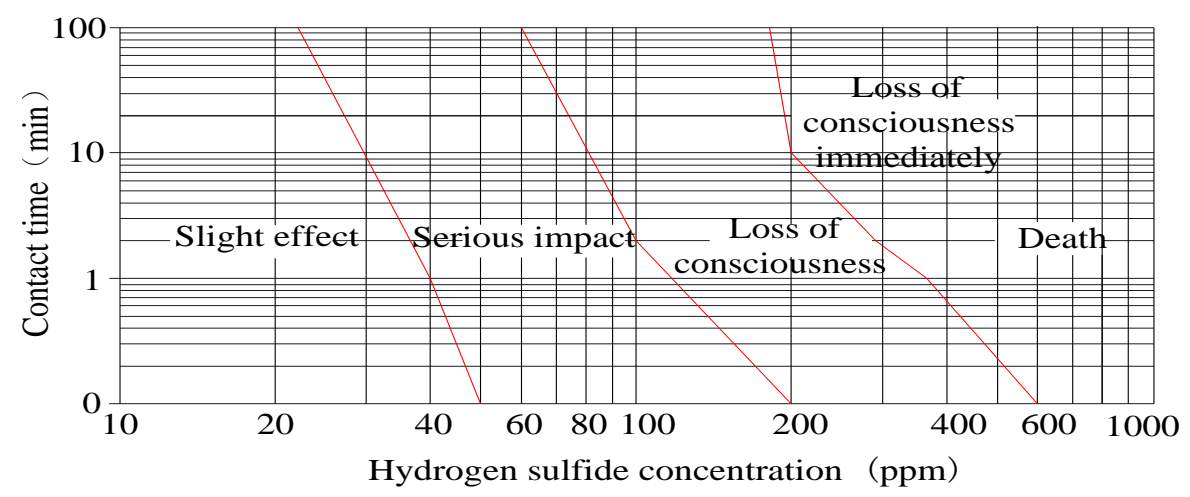

Figure 1. Physiological influence to human of $\mathrm{H}_{2} \mathrm{~S}$

(2) Pollution to the environment. In the combustion process or in the atmosphere, $\mathrm{H}_{2} \mathrm{~S}$ will be quickly oxidized to sulfur dioxide, which will increase the concentration of $\mathrm{SO}_{2}$ in the atmosphere to damage the plants and animals. Furthermore, it is also the main reason for the formation of acid rain (smog). Sulfate-reducing bacteria (SRB) is considered to be one of the main causes of corrosion of industrial equipment (Wei et al., 2014). $\mathrm{H}_{2} \mathrm{~S}$ in the water and air has a strong corrosion effect on concrete, electrical equipment, pipe networks, metals and plastics. When the $\mathrm{H}_{2} \mathrm{~S}$ content in the water exceeds 0.5 to $1.0 \mathrm{mg} / \mathrm{L}$, it will cause great harm to the aquaculture (Ren et al., 2009).

$\mathrm{H}_{2} \mathrm{~S}$ is estimated to account for 100 million tons into the atmosphere per year in the world, of which about 3 million tons are produced annually by humans. The majority of the remaining $\mathrm{H}_{2} \mathrm{~S}$ produce naturally, mainly derived from the metabolic activities of producing $\mathrm{H}_{2} \mathrm{~S}$ sulfate-reducing bacteria. Therefore, SRB is the most important biological source for $\mathrm{H}_{2} \mathrm{~S}$ production. Therefore, the study on the physiological characteristics of SRB and the formation mechanism of $\mathrm{H}_{2} \mathrm{~S}$ under BSR can provide reference for revealing the laws of sulfur geochemical cycling and ecological environment.

\section{Activity characteristics of SRB}

The group SRB is heterotrophic and mixed that can utilise sulfates, sulfites, thiosulfates, sulfur, or other oxidized sulfides as electron acceptors to catabolize organic 
materials and form $\mathrm{H}_{2} \mathrm{~S}$ (Gibson, 1990; Xiao et al., 2011). 18 genera and more than 40 species of SRB have been studied respectively. The names and characteristics of some genera are shown in Table 1 (Ren et al., 2009; Liao, 2004). The common 9 genera mainly involve Desulfovibrio which does not produce spores and Desulfotomaculum which produce spores. The former is generally medium or low temperature, and it is likely to die when the temperature exceeds $43{ }^{\circ} \mathrm{C}$. The latter is generally medium temperature or high temperature (Luptakova et al., 2005).

Table 1. Characteristics of SRB

\begin{tabular}{c|c|c|c}
\hline Name & Features & Exercisability & Growth T $\left({ }^{\circ} \mathbf{C}\right)$ \\
\hline Desulfovibrio & No spores, curved rods & + & $25-40$ \\
Desulfomicrobium & Rod-shaped, no spores & $+/-$ & $25-40$ \\
Desulfobollus & curved & $+/-$ & \\
Desulfotomaculum & Straight or curved rod & + & $25-40,40-65$ \\
Desulfobacter & Round, rod-shaped, without spores & $+/-$ & $20-23$ \\
Desulfococcus & Spheroidal, no spores & $-/+$ & $28-35$ \\
Desulfosarcina & Stacking, without spores & $+/-$ & 33 \\
Desulfoarculus & curved & $+/-$ & 37 \\
Desulfomonile & Rod-shaped, spheroidal & - & $25-40$ \\
Desulfobulbus & Oval, shape of Lemon, No spores & $-/+$ & \\
Desulfacinum & Spheroidal or oval type & & $65-70$ \\
Thermodesul fobocterium & Small shape, arc, rod & & $28-32$ \\
Desulfobacula & Oval & & $20-35$ \\
Desul fonema & Screw shape, no spores & slide & $+/-$ \\
Desulfobacterium & Round, rod-shaped & & \\
\hline
\end{tabular}

The group SRB is heterotrophic and mixed, and it survives in facultative anaerobic environment. The suitable grow temperature is between -5 and $75{ }^{\circ} \mathrm{C}$. Some strains can grow below $-5{ }^{\circ} \mathrm{C}$, and some with spore species can withstand high temperatures of $80{ }^{\circ} \mathrm{C}$. The optimum growth temperature for most mesophilic SRB is $28 \sim 38{ }^{\circ} \mathrm{C}$, and some can grow in the condition of $45^{\circ} \mathrm{C}$ (Larry, 1995). The surviving $\mathrm{pH}$ value of SRB is 4 to 9.5. Most SRBs are neutrophils. The most suitable pH is $6.5 \sim 7.8$ (Vallero et al., 2005). SRB can survive in salinity greater than $1 \mathrm{~g} / \mathrm{L}$ water. The best growth salinity is $100 \mathrm{~g} / \mathrm{L}$, and the upper limit reaches to $240 \mathrm{~g} / \mathrm{L}$. Some SRBs are halophilic, and they can be detected in some high-salt (such as salt lakes, the Dead Sea) ecosystems. Most of the halophilic bacteria isolated in the laboratory are mild halophilic bacteria (suitable salinity ranged from 1 to 4\%), and rarely isolated moderately halophilic bacteria (Zhao et al., 1995). The growth of SRB is generally lower than $-150 \mathrm{mV}$ in Eh (Barton et al., 1995). $\mathrm{Fe}^{2+}$ is the active component of various enzymes in SRB cells. Decreasing the concentration of $\mathrm{Fe}^{2+}$ ions can reduce the growth rate of SRB.

The carbon sources used by different strains of SRB are different. The carbon source not only increases the amount of bioenergy required, but also acts as an electron donor to reduction and dissimilation sulfates. The most common source is the use of $\mathrm{C}_{3}, \mathrm{C}_{4}$ fatty acids. In addition, the sources as some volatile fatty acids and easily fermented substances are also applied. Stephenson et al. (Stephensonl et al., 1931) presented that 
hydrogenases contained in SRBs and (Jannasch, 1988) illustrated that 33 out of 39 SRBs can absorb hydrogen at $28^{\circ} \mathrm{C}$.

\section{Formation mechanism of $\mathrm{H}_{2} \mathrm{~S}$ by SRB}

SRB can produce $\mathrm{H}_{2} \mathrm{~S}$ by assimilation of sulfates, or degradation of sulfur-containing organics (mainly cysteine). The former has a small yield and is quickly assimilated into organic sulfur compounds. The latter, with a larger yield, is the main formation of $\mathrm{H}_{2} \mathrm{~S}$ (Luhachack et al., 2014).

\section{The metabolic mechanism of sulfate as a sulfur source}

The metabolic process of SRB with sulfate as sulfur source can be divided into three stages. Decomposition, electron transfer, and oxidation, as shown in Figure 2 (Xu et al., 2009).

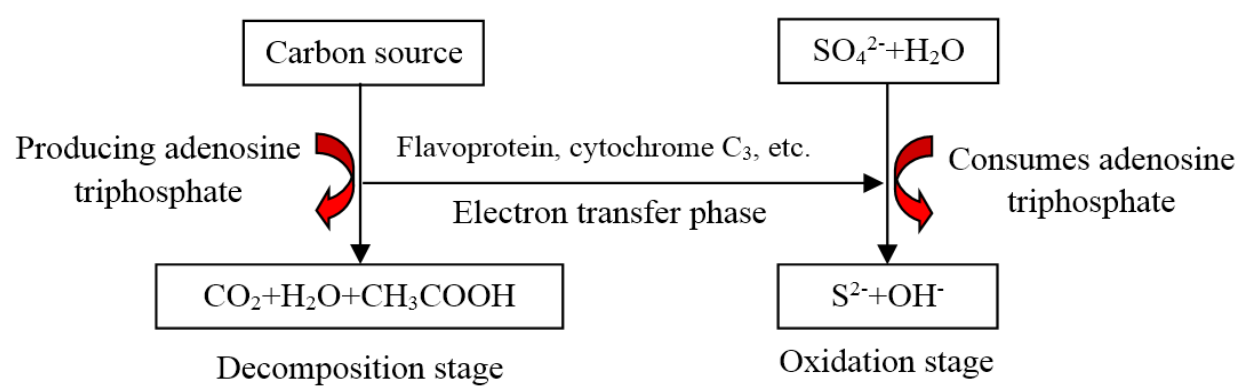

Figure 2. The metabolic process of SRB with sulfate as a sulfur source

(1) Decomposition stage. Sulfates are highly thermostable. Under anaerobic conditions, the sulfate ion $\left(\mathrm{SO}_{4}{ }^{2-}\right)$ first accumulates out of cell and then enters the cell of SRB, while organics produce adenosine triphosphate (ATP) and energetic electrons through substrate level phosphorlation. Thereafter, $\mathrm{SO}_{4}{ }^{2-}$ is activated by ATP sulfurylase to produce pyrophosphoric acid (PPi) and adenosine-5'-phosphosulfate (APS), PPi quickly decomposed into inorganic phosphate (Pi) (Zhao et al., 1997), stepwise reaction formulas are shown Equation 1 and 2, and total reaction formula is shown in Equation 3.

$$
\begin{gathered}
\mathrm{SO}_{4}{ }^{2-}+\mathrm{ATP}+2 \mathrm{H}^{+} \stackrel{\text { ATP sulfurylase }}{\longrightarrow} \mathrm{APS}+\mathrm{PPi} \\
\mathrm{PPi}+\mathrm{H}_{2} \mathrm{O} \stackrel{\text { Pyrophosphatase }}{\longrightarrow} 2 \mathrm{Pi} \\
\mathrm{SO}_{4}{ }^{2-}+\mathrm{ATP}+2 \mathrm{H}^{+}+\mathrm{H}_{2} \mathrm{O} \rightarrow \text { APS }+2 \mathrm{Pi}
\end{gathered}
$$

(2) Electron transfer stage. In the previous stage, the energetic electrons released by energy are transferred step by step through SRB-specific electron transport chains (such as flavoprotein, cytochrome $\mathrm{C}_{3}$, etc.). Affected by APS reductase, APS is continuously decomposed to sulfite and adenosine monophosphate (AMP). Sulfite is dehydrated into pyrosulfite $\left(\mathrm{S}_{2} \mathrm{O}_{5}{ }^{2-}\right) \cdot \mathrm{S}_{2} \mathrm{O}_{5}{ }^{2-}$ is extremely unstable and then would be converted to the intermediate dithionite $\left(\mathrm{S}_{2} \mathrm{O}_{4}{ }^{2-}\right)$. Afterwards, $\mathrm{S}_{2} \mathrm{O}_{4}{ }^{2-}$ is rapidly reducted to trithionate 
$\left(\mathrm{S}_{3} \mathrm{O}_{6}{ }^{2-}\right)$, and $\mathrm{S}_{3} \mathrm{O}_{6}{ }^{2-}$ is broken down to thiosulfate $\left(\mathrm{S}_{2} \mathrm{O}_{3}{ }^{2-}\right)$ and sulphite $\left(\mathrm{SO}_{3}{ }^{2-}\right)$. The reaction formula is shown in Equations 4-6, and the electron transfer is shown in Figure 3 (Bradley et al., 2011).

E-FAD + Electronic carrier $(\mathrm{RED}) \leftrightarrow$ Electronic carrier $(\mathrm{OX})+\mathrm{E}-\mathrm{FADH}_{2}$ (Eq.4)

$$
\begin{gathered}
\text { E-FADH }{ }_{2}+\text { APS } \leftrightarrow \text { E-FADH } 2\left(\mathrm{SO}_{3}{ }^{2-}\right)+\text { AMP } \\
\text { E- } \mathrm{ADH}_{2}\left(\mathrm{SO}_{3}\right) \leftrightarrow \mathrm{E}-\mathrm{FAD}+\mathrm{SO}_{3}{ }^{2-}
\end{gathered}
$$

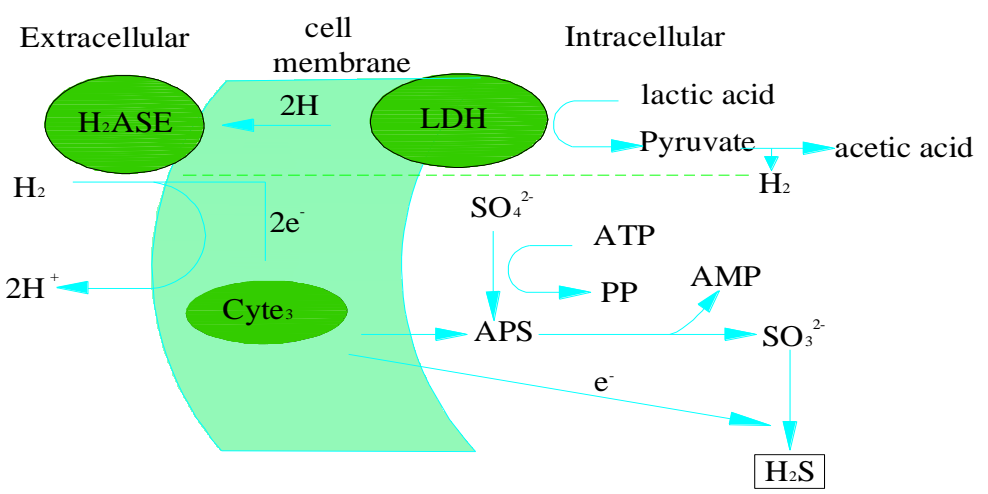

Figure 3. Electron transfer process of SRB. ATP - adenosine triphosphate; PP Polypyrrole; APS - adenosine-5'-phosphosulfate; AMP - adenosine monophosphate; LDH-lactate dehydrogenase

(3) Oxidation stage. The electrons are transferred to the oxidized sulfur elements $\left(\mathrm{S}_{2} \mathrm{O}_{3}{ }^{2-}, \mathrm{SO}_{4}{ }^{2-}, \mathrm{SO}_{3}{ }^{2-}\right)$, which consume a lot of ATP. From $\mathrm{SO}_{4}{ }^{2-}$ to $\mathrm{S}^{2-}$, there are 8 electron transfers. ATP thiokinase catalyzes the adsorption of $\mathrm{SO}_{4}{ }^{2-}$ to ATP phosphatase, which in turn forms APS. The sulfated portion of APS is directly reduced to sulfite and releases AMP. The initial product of sulfate reduction is sulfite. Once the sulfite is formed, the reaction process shown in Figure 4 can be proceed (Bradley et al., 2011), finally producing $\mathrm{H}_{2} \mathrm{~S}, \mathrm{H}_{2} \mathrm{~S}$ and the reaction formula is shown in Equation 7.

$$
\mathrm{SO}_{4}{ }^{2-}+8 \mathrm{e}^{-}+10 \mathrm{H}^{+} \rightarrow \mathrm{H}_{2} \mathrm{~S} \uparrow+4 \mathrm{H}_{2} \mathrm{O}
$$

The followings may be the reaction pathway from $\mathrm{SO}_{3}{ }^{2-}$ to $\mathrm{H}_{2} \mathrm{~S}$ formation (Cai et al., 2009). (1) 3 consecutive two-electron transfer, forming $\mathrm{S}_{3} \mathrm{O}_{6}{ }^{2-}$ and thiosulfate $\left(\mathrm{SO}_{3}{ }^{2-}\right.$ $\rightarrow \mathrm{S}_{3} \mathrm{O}_{6}{ }^{2-} \rightarrow \mathrm{S}_{2} \mathrm{O}_{3}{ }^{2-} \rightarrow \mathrm{S}^{2-} \rightarrow \mathrm{H}_{2} \mathrm{~S}$ ). (2) $\mathrm{SO}_{3}{ }^{2-}$ directly lose 6 electrons, the above-mentioned intermediate product is not formed and is referred to as coordinated 6-electron reaction, namely $\mathrm{SO}_{3}{ }^{2-}+6 \mathrm{e}^{-}+8 \mathrm{H}^{+} \rightarrow \mathrm{H}_{2} \mathrm{~S}+3 \mathrm{H}_{2} \mathrm{O}$. (3) In the continuous two-electron transfer process, the reverse reaction may also occur. The reaction formula is shown in Equation 8.

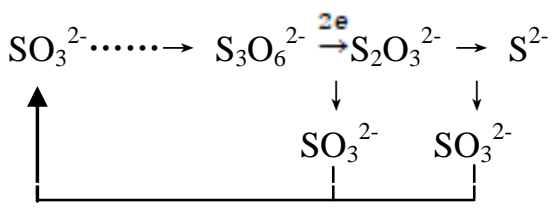




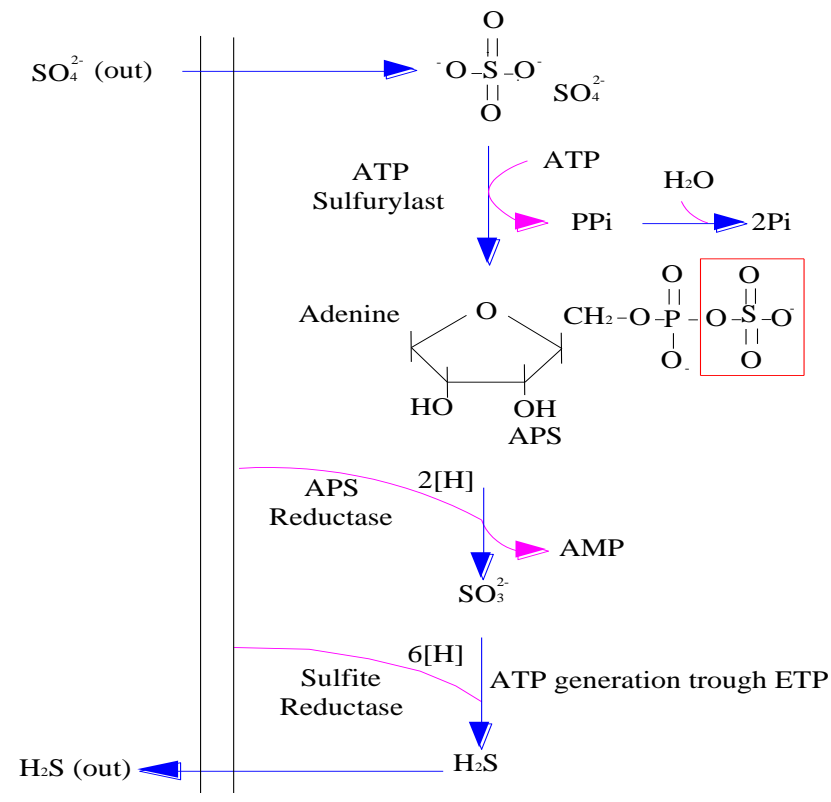

Figure 4. Diagram of dissimilatory sulfate reduction. ATP - adenosine triphosphate; $P P i$ pyrophosphoric acid; Pi - inorganic phosphate; APS - adenosine-5'-phosphosulfate; AMP adenosine monophosphate; ETP - electron transport particles

SRB utilizes lactate as an electron donor and $\mathrm{SO}_{4}{ }^{2-}$ as an electron acceptor for BSR action. There are three enzymes involved in the sulfite reduction process during the reduction of $\mathrm{SO}_{3}{ }^{2-}$ to $\mathrm{S}^{2-}$, namely $\mathrm{S}_{3} \mathrm{O}_{6}{ }^{2-}$ forming enzyme, $\mathrm{S}_{3} \mathrm{O}_{6}{ }^{2-}$ reductase or thiosulfate-forming enzyme and thiosulfate reductase. In BSR, SRB produces and accumulates large amounts of $\mathrm{S}^{2-}$ or $\mathrm{HS}^{-}$in the cells. When the concentration of $\mathrm{S}^{2-}$ or $\mathrm{HS}^{-}$in the cell reaches to a certain value, it will be released into the solution through the cell membrane, increasing the concentration of $\mathrm{S}^{2-}$ in the surroundings, which leads to the change in the redox potential of the environment and the concentration of related ions (Ren et al., 2009; Pérez et al., 2001). SRB metabolic $\mathrm{H}_{2} \mathrm{~S}$ formation process is shown in Figure 5 (Peck et al., 1982).

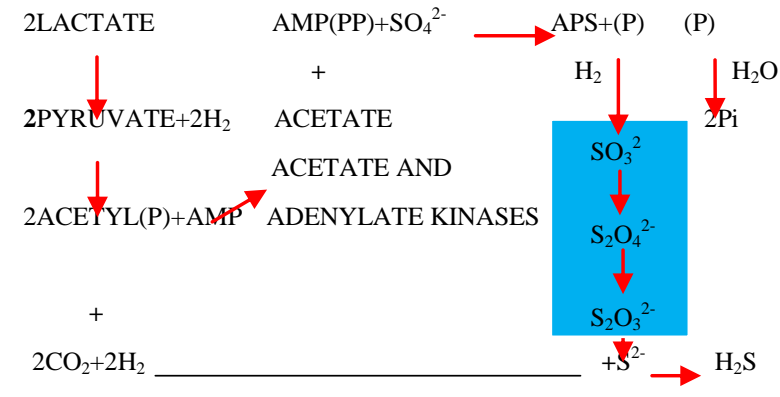

Figure 5. Flowchart of SRB metabolism forming $\mathrm{H}_{2} \mathrm{~S}$. Pi - inorganic phosphate; APS adenosine-5'-phosphosulfate; $P$ - Phosphorum

The carbon of dibenzothiophene (DBT) as metabolic material is reacted with SRB to decompose the aromatic ring structure and form a sulfur-containing compound. The Kodama pathway is shown in Figure 6 (Kodama et al., 2008). 


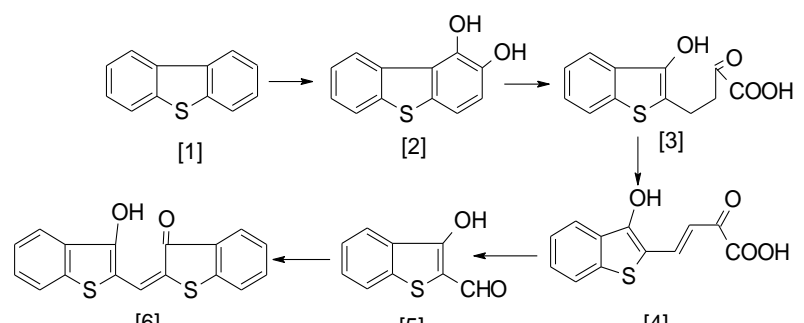

[6]

[5]

$[4]$

Figure 6. Kodama pathway of metabolic mechanism of SRB use the carbon

\section{The metabolic mechanism of organo-sulfur compounds as a sulfur source}

SRB is degraded by sulfur-containing organic substances (such as sulfur amino acids, cysteine, cysteine, sulfanilic acid, methionine, sulfonate, glutathione, etc.) as sulfur sources to produce $\mathrm{H}_{2} \mathrm{~S}$. The degradation process differs depending on the types of SRB. Usually some SRBs will completely degrade some polymer-containing organic compounds to produce $\mathrm{H}_{2} \mathrm{~S}$. Some will only degrade them into relatively lowmolecular-weight sulfur-containing organic compounds such as mercaptans, and then other species. The SRB degrades it to the end product such as $\mathrm{H}_{2} \mathrm{~S}$ (Ren et al., 2001). The sulphur-containing organic degradation reaction can be summarized as shown in Equation 9.

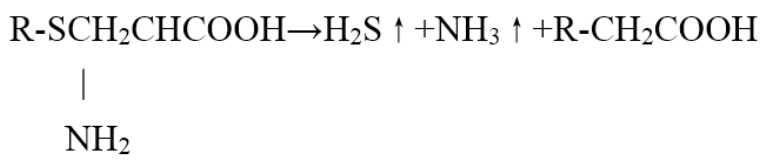

The 4S pathway of sulfur metabolism (sulphoxide/sulphone/sulponate/sulphate) (Isbister et al., 1998). For different strains, the $4 \mathrm{~S}$ pathway is not exactly the same, all of which have a common role in the C-S bond. For example, Rhodococcus sp. strain IGTS8 bacteria are considered to have two desulfurization pathways (Ma et al., 2000), as shown in Figure 7.

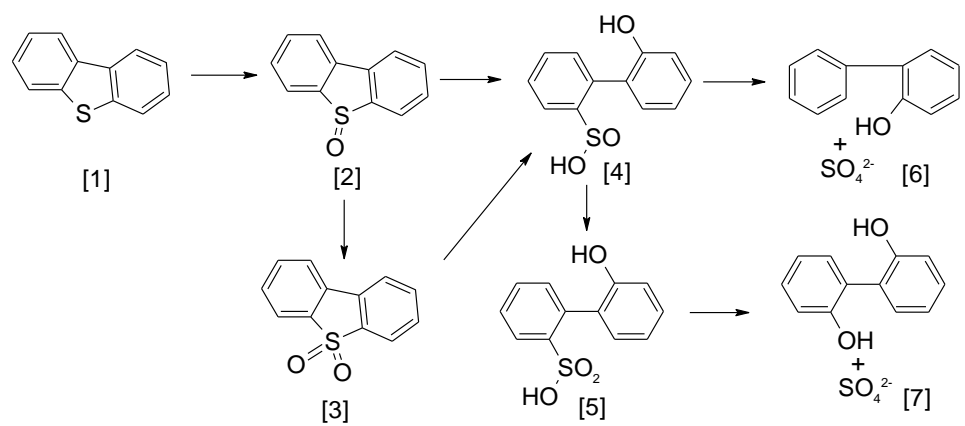

Figure 7. The 4S pathway of Rhodococcus sp. strain IGTS8 bacterium

The sulfur in DBT will generate $\mathrm{SO}_{4}{ }^{2-}, \mathrm{SO}_{3}{ }^{2-}$ and 2, 2'- 2- Dihydroxybiphenyl or 2hydroxybiphenyl and sulphur containing compounds after 4 steps. 


\section{Metabolic pathway of SRB}

The sulfur cycle is an important geochemical cycle in the Earth's environmental system, and SRB plays an indispensable role in this system. The basic process can be described as the following (Rasch et al., 2000): when the onshore volcanic eruptions, sulfur in the earth's crust and magma is released into the atmosphere in the form of $\mathrm{H}_{2} \mathrm{~S}$, sulfate and $\mathrm{SO}_{2}$. Some of the sulfur emitted from the volcanic eruption of the submarine is dissolved in sea water and some of it is released into the atmosphere by gaseous sulfides. Sulfur in the atmosphere circulates through sulfuric acid or sulphate aerosols into the biosphere, pedosphere and hydrospheres. These sulphur compounds are then passively absorbed and assimilated by plants and animals. The absorbed sulfur forms the body of plants and animals. Animal and plant residues are decomposed by microorganisms, and sulfur becomes $\mathrm{H}_{2} \mathrm{~S}$ escaped into the atmosphere or deposited into peat. The reduction of sulphate in water is accomplished by reverse sulfidation of various sulfate-reducing bacteria. In the absence of oxygen, sulfates are produced into $\mathrm{H}_{2} \mathrm{~S}$ as hydrogen acceptors. Sulfate, $\mathrm{H}_{2} \mathrm{~S}$ and sulfur is mineralized under the common action of aqueous medium and organic matter to generate organic sulfide or inorganic sulfide. The sulfur cycle in global ecosystem is shown in Figure 8 (Deng et al., 2013).

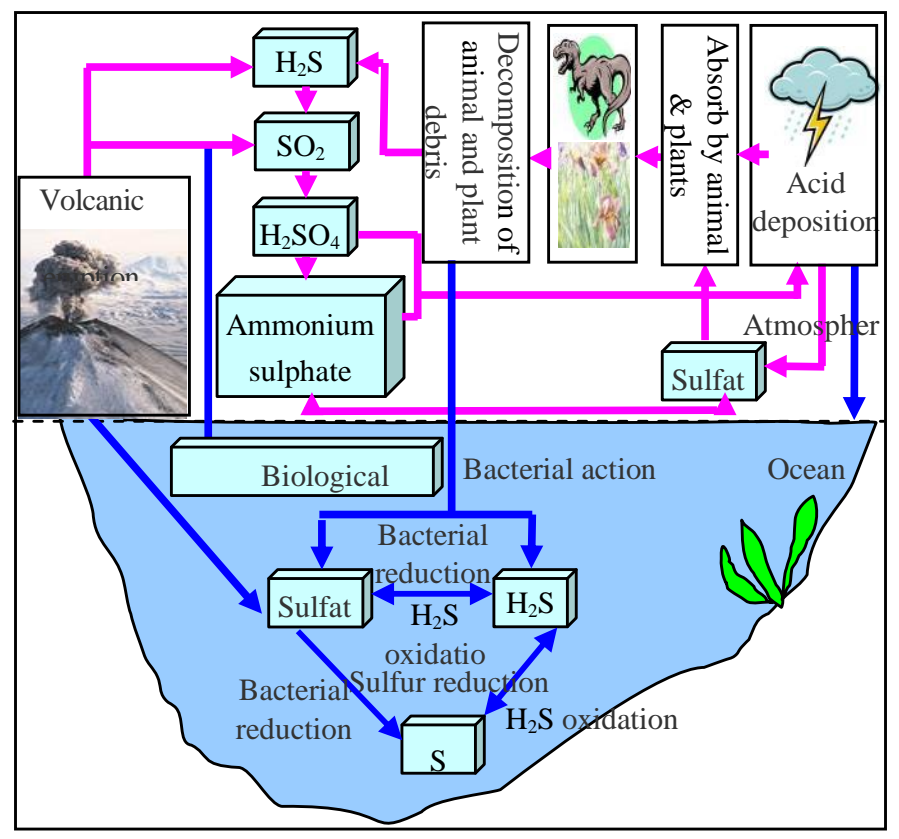

Figure 8. Sulfur cycle in the Earth's environmental systems

It has been known that due to the action of microorganisms, there are obvious redox zone from the top down of shallow sediment layers in the seabed, which can be divided into oxidation zone, weak oxidation zone, reduction zone and methanogenic zone in turn. The SRB is mainly distributed in the reduction zone in Figure 9, where it plays a dominant role and produces $\mathrm{H}_{2} \mathrm{~S}$ (Berner, 1981; Froelich et al., 1979).

There are also four sequential redox zones in the sulfate reduction zone, iron reduction zone, nitrate reduction zone and oxidation zone in landfill leachate sites, as shown in Figure 10 (Zhou et al., 2008). The biocenosis structure in each zone has obvious bacterial species properties. Accordingly, sulfate-reducing bacteria, iron- 
reducing bacteria (IRB) and denitrifying bacteria (NRB) are the dominant bacterial groups. The distribution of redox zone and microbial flora indicates that there is a certain overlap between the redox zones, where the sulfate reduction zone is the main zone where malodorous gas $\left(\mathrm{H}_{2} \mathrm{~S}\right)$ is generated.

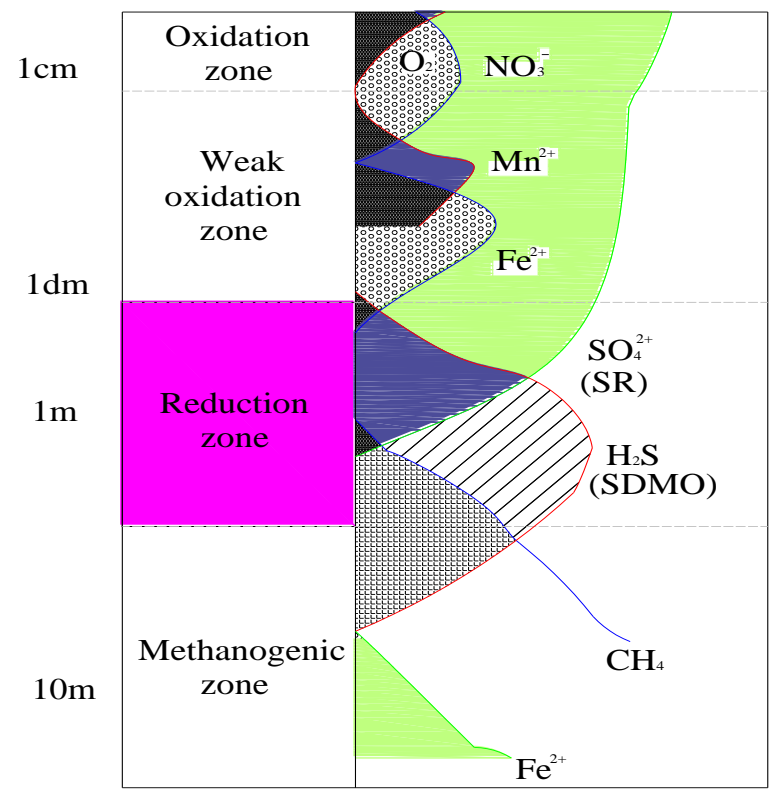

Figure 9. SRB and redox zone division in submarine deposits

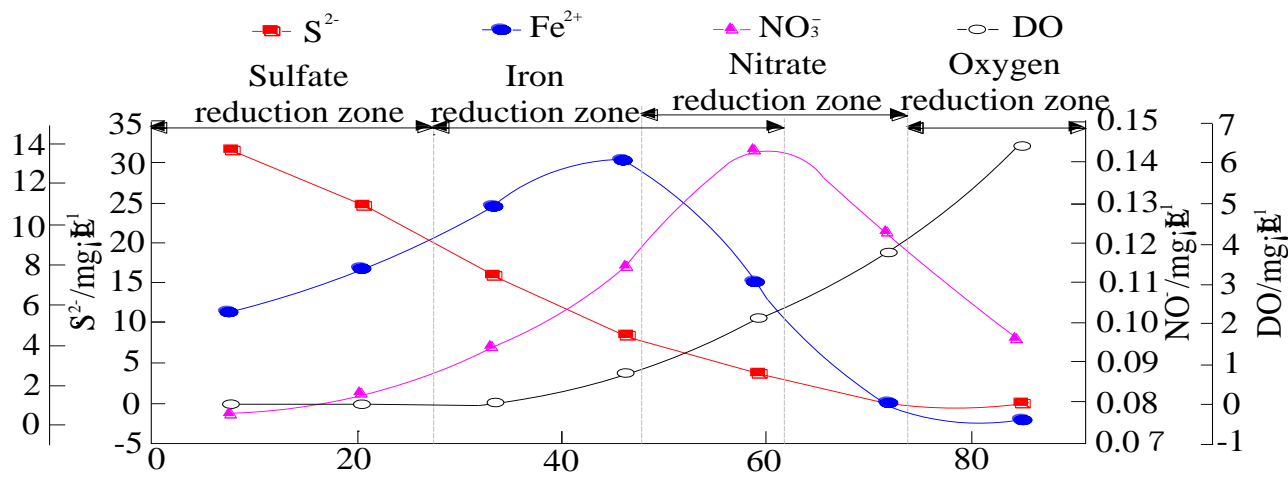

Figure 10. Distribution of redox zones in landfills

Organic sulfur compounds are produced mainly in humification stage. $\mathrm{H}_{2} \mathrm{~S}, \mathrm{CH}_{3} \mathrm{SH}$, and $\left(\mathrm{CH}_{3}\right) \mathrm{S}, \mathrm{S}^{0}$, or polysulfide compounds generated by the bacteria dissociation are oxidized to sulfates in an oxygen-rich environment. When the interface between the aqueous medium and the sediment exists in anoxic environment and the sulphate solubility reaches a certain value, $\mathrm{SRB}$ is metabolized by $\mathrm{SO}_{4}{ }^{2-}$ as a sulphur source, and BSR works after decomposition, electron transfer and oxidation. The metabolic activity of SRB reduces the solubility of $\mathrm{SO}_{4}{ }^{2-}$ and releases $\mathrm{H}_{2} \mathrm{~S}, \mathrm{HS}^{-}$, or $\mathrm{S}^{0}$. $\mathrm{HS}^{-}$or $\mathrm{S}^{0}$ can react with organic matter to form organic sulfur, which can also react with iron ions to form pyrite. If the active iron ion is absent in the system and the $\mathrm{SO}_{4}{ }^{2-}$ content is relatively 
sufficient, a large amount of secondary organic sulfur compounds may be produced under suitable conditions, which is shown in Figure 11 (Dai et al., 1996).

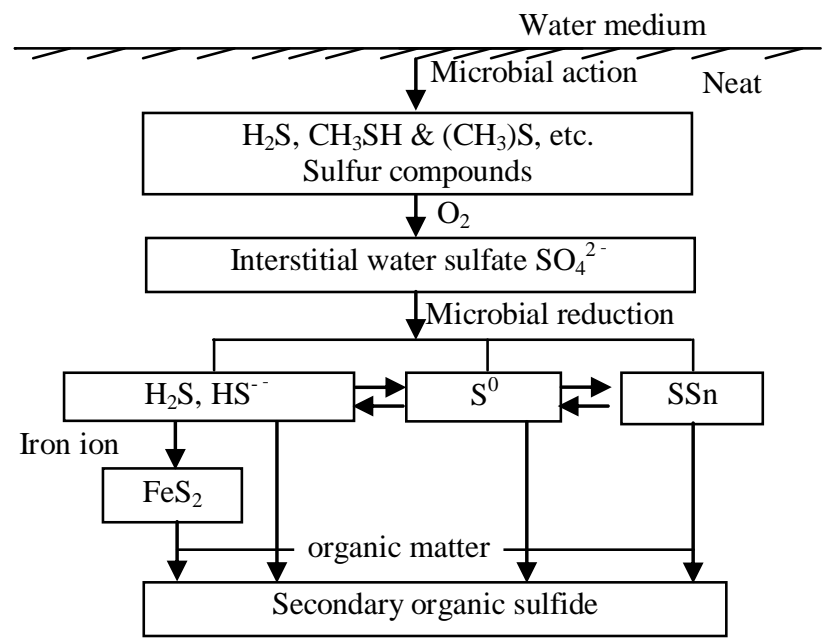

Figure 11. The evolution of organic sulfur

In sedimentary formations, due to the interaction between sedimentary factors and ecological factors, three different biological systems are formed, each of which is dominated by different microbial populations, namely the Aerobic microbial zones, sulfate reduction zones and organisms Methane generation zone. In the sulfate reduction zone, $\mathrm{H}_{2} \mathrm{~S}$ may be generated as shown in Figure 12 (Lin et al., 2015).

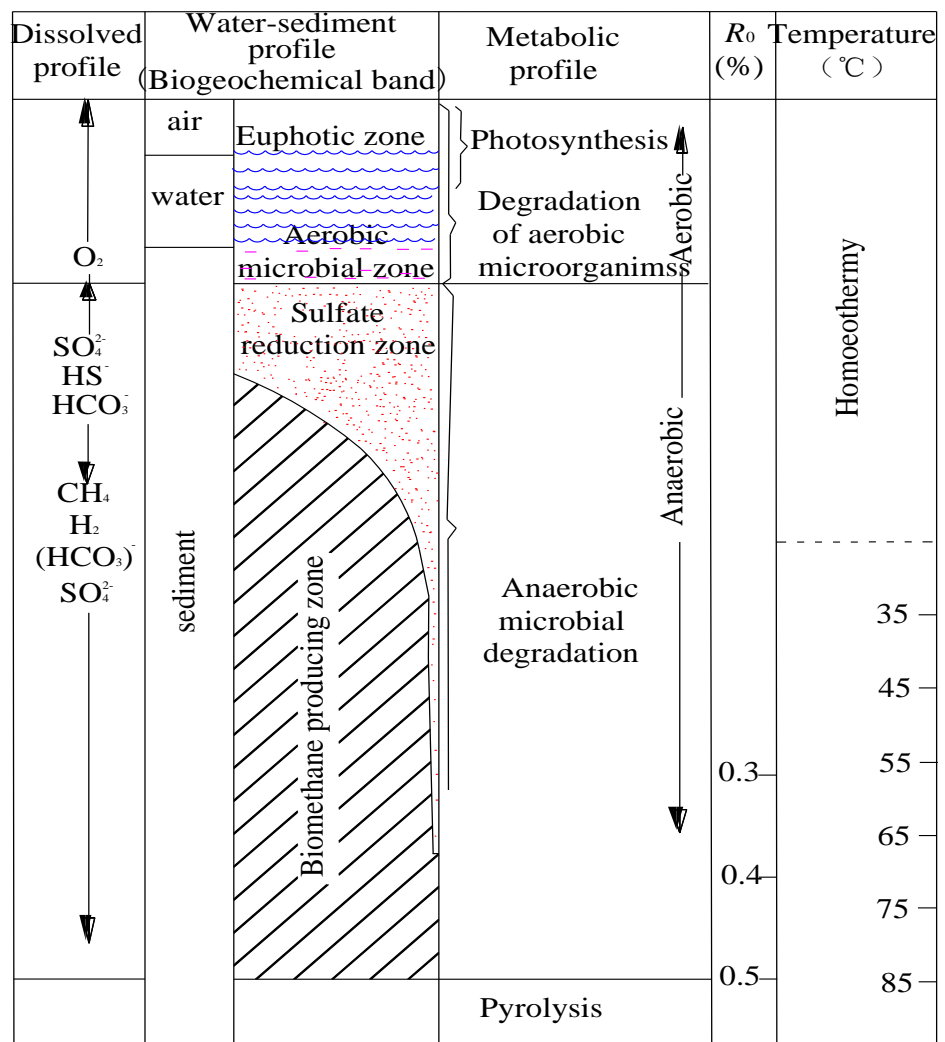

Figure 12. Schematic diagram of biogenic gas phase in sedimentary strata 
(1) In a reducing environment, anaerobic sulfate-reducing bacteria reduce the sulfate in the water to form $\mathrm{H}_{2} \mathrm{~S}$ (Eq. 10).

$$
\mathrm{SO}_{4}{ }^{2-}+2 \mathrm{C}+\mathrm{H}_{2} \mathrm{O} \stackrel{\mathrm{BSR}}{\rightarrow}{ }_{2} \mathrm{~S} \uparrow+4 \mathrm{HCO}_{3}^{-}
$$

(2) In the oxygen-enriched oxidizing environment, biosulfur and sulfuric acid are formed under the action of sulfur oxidizing bacteria (Eq. 11).

$$
2 \mathrm{H}_{2} \mathrm{~S}+\mathrm{O}_{2} \rightarrow 2 \mathrm{H}_{2} \mathrm{O}+2 \mathrm{~S}, 2 \mathrm{~S}+3 \mathrm{O}_{2}+2 \mathrm{H}_{2} \mathrm{O} \rightarrow 2 \mathrm{H}_{2} \mathrm{SO}_{4}
$$

(3) If the solution contains $\mathrm{Fe}^{2+}$, native pyrite framboids and microbial dolomite will be appeared. The principle is that $\mathrm{Fe}^{2+}$ reacts with $\mathrm{H}_{2} \mathrm{~S}$ to produce pyrite $(E q .12)$.

$$
\mathrm{Fe}^{2+}+\mathrm{S}^{2-} \rightarrow \mathrm{FeS} \downarrow
$$

SRB has become an active participant in the early diagenesis process (Brüchert et al., 2001; Krause et al., 2012). Krause et al. found that in anoxic, low-temperature $\left(21^{\circ} \mathrm{C}\right)$ modern seawater (normal salinity and $\mathrm{Mg}^{2+} / \mathrm{Ca}^{2+}$ values), BSR action occurs under the action of SRB, which can lead to the formation of $\mathrm{H}_{2} \mathrm{~S}$ and precipitation of dolomite. Its formation model is shown in Figure 13. The possible reaction formulas are shown in Equations 13 and 14 (Glud et al., 1998).

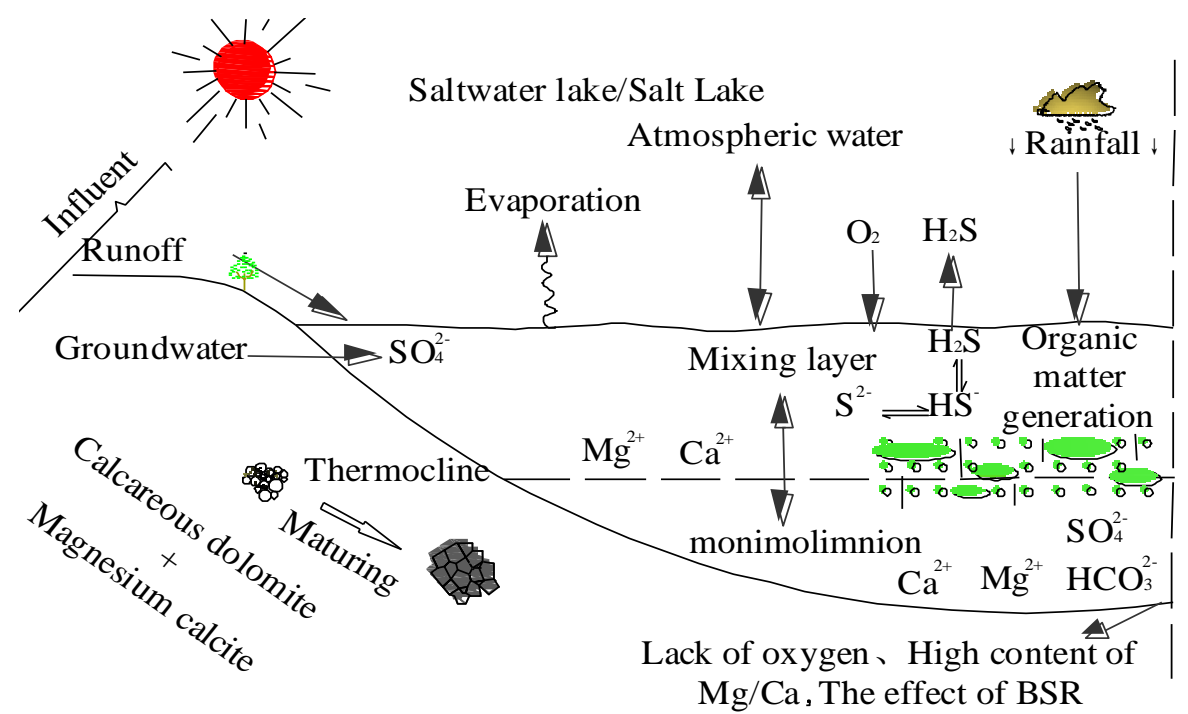

Figure 13. Microbial mechanism model of primary dolomite in lake system

$$
\begin{gathered}
2 \mathrm{CH}_{2} \mathrm{O}+\mathrm{SO}_{4}{ }^{2-} \stackrel{\mathrm{SRB}}{\rightarrow} \mathrm{S} \uparrow+2 \mathrm{HCO}_{3}{ }^{-} \\
2 \mathrm{HCO}^{3-}+\mathrm{Mg}^{2+}+\mathrm{Ca}^{2+} \rightarrow \mathrm{CaMg}\left(\mathrm{CO}_{3}\right)_{2}+2 \mathrm{H}^{+}
\end{gathered}
$$

In the formation of dolomite and $\mathrm{H}_{2} \mathrm{~S}$ under the action of BSR in the salt lake (seawater) system, the SRB metabolic activity and intracellular reaction processes can be described as shown in Figure 14 and Equations 15-18 (Corzo et al., 2005). 


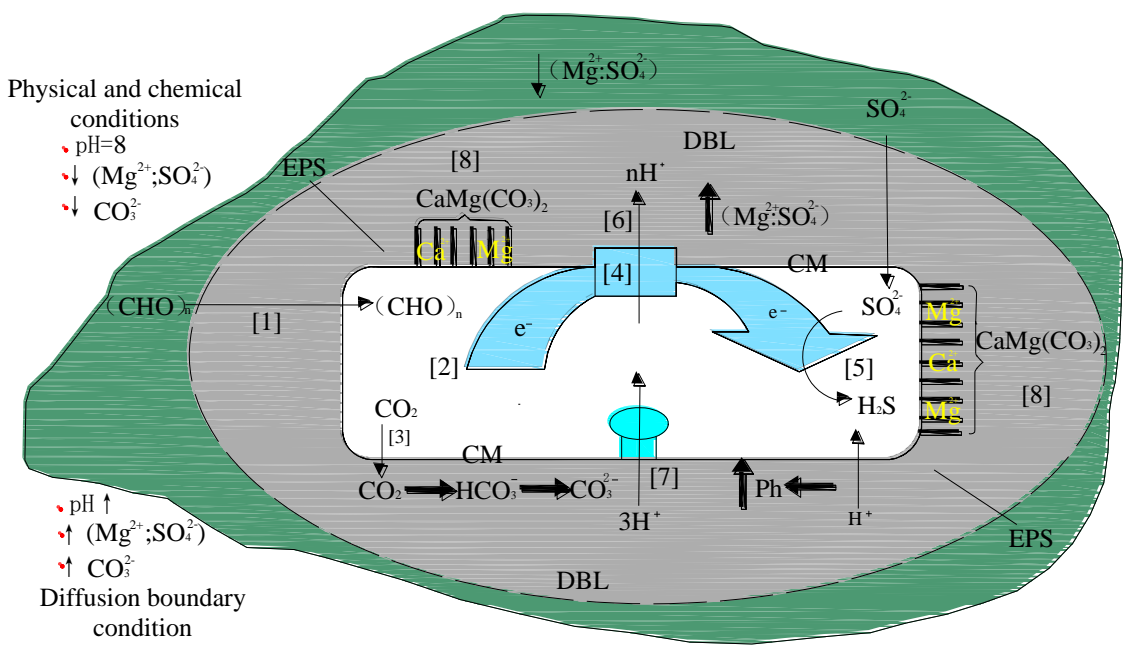

Figure 14. SRB metabolic activity and intracellular reaction process. DBL - diffusion boundary layer; EPS - cell membrane and outer polymer matrix; CM - cell membranes

$$
\begin{gathered}
2 \mathrm{CH}_{2} \mathrm{O}+2 \mathrm{H}_{2} \mathrm{O} \rightarrow 2 \mathrm{CO}_{2}+4 \mathrm{H}_{2} \\
\mathrm{CO}_{2}+\mathrm{H}_{2} \mathrm{O} \rightarrow \mathrm{HCO}_{3}{ }^{-}+\mathrm{H}^{+}, \mathrm{HCO}_{3}{ }^{-} \rightarrow \mathrm{CO}_{3}{ }^{2-}+\mathrm{H}^{+} \\
\mathrm{SO}_{4}{ }^{2-}+8 \mathrm{e}^{-}+10 \mathrm{H}^{+} \rightarrow \mathrm{H}_{2} \mathrm{~S}+4 \mathrm{H}_{2} \mathrm{O}(\mathrm{BSR}) \\
2 \mathrm{CO}_{3}{ }^{2-}+\mathrm{Mg}^{2+}+\mathrm{Ca}^{2+} \rightarrow \mathrm{CaMg}\left(\mathrm{CO}_{3}\right)_{2}
\end{gathered}
$$

In the process of degrading organic matter, $\mathrm{SRB}$ in solution can reduce the $\mathrm{SO}_{4}{ }^{2-}$ solubility, increase the concentration of $\mathrm{Mg}^{2+} / \mathrm{SO}_{4}{ }^{2-}, \mathrm{pH}$ value, $\mathrm{HCO}_{3}{ }^{-}$concentration and dolomite saturation, and generate $\mathrm{H}_{2} \mathrm{~S}$, which will produce a micro-environment conducive to the precipitation of dolomite. SRB cells, which are in the dark green area, are surrounded by the effective diffusion boundary layer (DBL) in the colour of the dark gray. The low-molecular-weight organic compounds in surroundings enter the cells [1], which are oxidized to $\mathrm{CO}_{2}$ [2, e.g. (Eq. 16)] and released to DBL [3, e.g. (Eq. 16)]. The ions formed by the oxidation of organic matter pass through cell-electron-transporting cell membranes (CM) [4] to $\mathrm{SO}_{4}{ }^{2-}$ and undergo a reduction to generate $\mathrm{H}_{2} \mathrm{~S}$ [5, e.g. (Eq. 17)]. The electron flow $\left(\mathrm{H}^{+}\right)$migrates to the DBL[6] through the anaerobic respiratory chain, forming an electrochemical gradient across the cell membrane and stimulating $\mathrm{H}^{+}$ entry via ATP synthetase. Hence, under fully constrained stoichiometry $\left(3 \mathrm{H}^{+}\right.$. ATP), the $\mathrm{H}+$ ion flux in these cells is coupled to ATP synthase [7]. Since these processes cause the cells to be negatively charged, $\mathrm{Ca}^{2+}$ and $\mathrm{Mg}^{2+}$ are adsorbed to the cell membrane and outer polymer matrix [8, e.g. (Eq. 18)] (Lith et al., 2010, 2003). Therefore, near the cell membrane and DBL, $\mathrm{H}_{2} \mathrm{~S}$ is formed and dolomite is produced and precipitated [8, e.g. (Eq. 18)].

\section{Conclusion}

In anaerobic (reduced) habitats, sulfate-reducing bacteria have a unique sulfatereducing activity. The physiological characteristics and mechanism of $\mathrm{H}_{2} \mathrm{~S}$ formation not only provide a basis for revealing the biogeochemical cycle of sulfur elements, 
which is conducive to the protection of the natural environment and the restoration of polluted ecosystems, and also provide a useful reference for the control of aerobic microorganisms.

The metabolic reduction process of SRB, using sulfate and sulfur-containing organic material as sulfur source, is not only related to sulfate-reducing bacteria, but also closely related to non-sulfate-reducing microorganisms. A large number of sulfur sources metabolized by SRB are converted into soluble intermediate organic products that can be used by non-SRBs in the metabolic system.

In the earth system, there are many places of metabolism of sulfate-reducing bacteria. And under the metabolism of SRB, BSR may occur to form $\mathrm{H}_{2} \mathrm{~S}$. The metabolites in various places are closely related to their micro-environment.

It finds that SRB is the most important biological source for $\mathrm{H}_{2} \mathrm{~S}$ production. The study on the formation mechanism of $\mathrm{H}_{2} \mathrm{~S}$ under BSR can provide meaningful reference for the disclosure of the geochemical cycle law of sulfur and the rules of the ecological environment, and supply with a helpful reference for the control of aerobic microorganisms.

Acknowledgements. This work was supported by "National Natural Science Foundation of China (51774116, U1504403)", "Scientific and Technological Project of Department of Science \& Technology of Henan Province (182102210320)" and "Postdoctoral Research Fund of Henan Province (2017)". In the study process, the authors are also grateful to Professor Mingju Liu of Henan Polytechnic University for his ardent guidance and help.

\section{REFERENCES}

[1] Barton, L. L. (1995): Sulfate-Reducing Bacteria. - Plenum Press, New York.

[2] Barton, L. L., Tomei, F. A. (1995): Characteristics and Activities of Sulfate-Reducing Bacteria. - Springer, New York, pp. 1-32.

[3] Berner, R. A. (1981): A new geochemical classification of sedimentary environments. Journal of Sedimentary Research 51(2): 359-365.

[4] Bradley, A. S., Leavitt, W. D., Johnston, D. T. (2011): Revisiting the dissimilatory sulfate reduction pathway. - Journal of Geobiology 9(5): 446-457.

[5] Brüchert, V., Knoblauch, C., Bo, B. J. (2001): Controls on stable sulfur isotope fractionation during bacterial sulfate reduction in Arctic sediments. - Journal of Geochimica Et Cosmochimica Acta 65(5): 763-776.

[6] Cai, J., Zheng, P., Zhang, L. (2009): Sulfate-reducing bacteria and their metabolic pathway. - Bulletin of Science and Technology 25(4): 427-431.

[7] Corzo, A. Luzon, M. J., Mayayo, M. et al. (2005): Carbonate mineralogy along a biogeochemical gradient in recent lacustrine sediments of gallocanta lake (Spain). Journal of Geomicrobiology Journal 22(6): 283-298.

[8] Dai, S., Liu, Y., Ren, D. (1996): The formation of sulphur in coal and its control factors. - Journal of Shandong Mining Institute 15(4): 7-11.

[9] Deng, Q., Liu, M., Zhao, F. et al. (2013): Geochemistry characteristics of sulfur in coals. - Journal of Disaster Advances 6: 234-240.

[10] Deng, Q., Liu, M., Cui, X. et al. (2017): A study of hydrogen sulfide genesis in coal mine of southeastern margin of Junggar Basin. - Journal of Earth Science Frontiers 24(5): 395401.

[11] Deng, Q., Wang, Y., Wu, X. et al. (2018): Research progress of prevention and control technology of hydrogen sulfide in coal mines. - Journal of Science Technology Review 36(2): $1-7$. 
[12] Froelich, P. N., Klinkhammer, G. P., Bender, M. L. et al. (1979): Early oxidation of organic matter in pelagic sediments of the eastern equatorial Atlantic suboxic diagenesis. - Journal of Geochimica et Cosmochimica Acta 43(7): 1075-1090.

[13] Gibson, G. R. (1990): Physiology and ecology of the sulfate-reducing bacteria. - Journal of Applied Bacteriology 69: 767-797.

[14] Glud, R. N., Holby, O., Hoffmann, F. et al. (1998): Benthic mineralization and exchange in Arctic sediments (Svalbard, Norway). - Journal of Marine Ecology Progress 173(8): 237-251.

[15] Isbister, J. D., Wyza, R. E., Lippold, J. et al. (1988): Bioprocessing of Coal. - In: Omenn, G. S. (ed.) Environmental Biotechnology, Reducing Risks from Environmental Chemicals through Biotechnology. Plenum Press, New York, pp. 281-293.

[16] Jannasch, H. W. (1988): Marine microbiology. - Journal of Bioscience 38(10): 711-712.

[17] Kodama, K., Umehara, K., Shimizu, K. et al. (2008): Identification of microbial products from dibenzothiophene and its proposed oxidation pathway. - Journal of the Agricultural Chemical Society of Japan 37(1): 45-50.

[18] Krause, S., Liebetrau, V., Gorb, S. et al. (2012): Microbial nucleation of Mg-rich dolomite in exopolymeric substances under anoxic modern seawater salinity. New insight into an old enigma. - Journal of Geology 40(7): 987-990.

[19] Liao, Y. (2004): Mechanism and Technology of Biological Desulfurization of Waste Water. - Chemical Industry Press, Beijing.

[20] Lin, X., Gao, G., Xu, Y. et al. (2015): Discussion on generation and evolution mode of biogenetic gas. - Journal of Special Oil and Gas Reservoirs 22(1): 1-7.

[21] Lith, Y. V., Warthmann, R., Vasconcelos, C. et al. (2003): Sulphate-reducing bacteria induce low-temperature $\mathrm{Ca}$-dolomite and high $\mathrm{Mg}$-calcite formation. - Journal of Geobiology 1(1): 71-79.

[22] Lith, Y. V., Warthmann, R., Vasconcelos, C. et al. (2010): Microbial fossilization in carbonate sediments. a result of the bacterial surface involvement in dolomite precipitation. - Journal of Sedimentology 50(2): 237-245.

[23] Luhachack, L., Nudler, E. (2014): Bacterial gasotransmitters. An innate defense against antibiotics. - Journal of Current Opinion in Microbiology 21: 13-17.

[24] Luptakova, A., Kusnierova, M. (2005): Bioremediation of acid mine drainage contaminated by SRB. - Journal of Hydrometallurgy 77(1-2): 97-102.

[25] Ma, C., Xu, P., Yu, J. (2000): Progress of microbial organo-desulfurization in fossil fuel. - Journal of Acta Biochimica et Biophysica Sinica 20(3): 55-59.

[26] Machel, H. G. (2001): Bacterial and thermochemical sulfate reduction in diagenetic settings - old and new insights. - Sedimentary Geology 140: 143-175.

[27] Martins, M., Faleiro, M. L., Barros, R. J. et al. (2009): Characterization and activity studies of highly heavy metal resistant sulphate reducing bacteria to be used in acid mine drain age decontamination. - Journal of Hazardous Materials 166(2-3): 706-713.

[28] Orr, W. L. (1974): Changes in sulfur content and isotopic ratios of sulfur during petroleum maturation - Study of Big Horn Basin Palaeozoic oils. - American Association of Petroleum Geologists Bulletin 58(11): 2295-2318.

[29] Peck, H. D. Jr., Legall, J. (1982): Biochemistry of dissimilatory sulphate reduction. Philosophical Transactions of the Royal Society of London 298(1093): 443-466.

[30] Pérez-Jiménez, J. R., Young, L. Y., Kerkhof, L. J. (2001): Molecular characterization of sulfate-reducing bacteria in anaerobic hydrocarbon-degrading consortia and pure cultures using the dissimilatory sulfite reductase (dsrAB) genes. - Fems Microbiology Ecology 35(2): 145-150.

[31] Rasch, P. J., Barth, M. C., Kiehl, J. T. et al. (2000): A description of the global sulfur cycle and its controlling processes in the NCAR CCM3. - J. Geophys. Re. 105: 13671385.

[32] Ren, N., Wang, A., Zhen, W. (2001): Ecology of SRB in anaerobic bio-treatment reactor. - Journal of Harbin University of C. E. \& Architecture 34(1): 39-44. 
[33] Ren, N., Wang, A., Zhao, Y. (2009): Ecology of Sulfate-Reducing Bacteria in Anaerobic Biotreatment Processes. - Science Press, Beijing.

[34] Stephensonl, M., Stickland, L. H. (1931): Hydrogenase. The reduction of sulphate to sulfide by molecular hydrogen. - Journal of Biochemical Journal (25): 215-220.

[35] Vallero, M. V. G., Lettinga, G., Lens, P. N. L. (2005) High rate sulfate reduction in a submerged anaerobic membrane bioreactor (SAMBaR) at high salinity. - Journal of Membrane Science 253(1-2): 217-232.

[36] Wei, J., Deng, Q., Liu, M. (2014): Hazards of hydrogen sulfide and control measures in Coal Mines. - Journal of Coal Technology 33(10): 269-272.

[37] Xiao, L., Zhang, L., Li, Y. (2011): Application of sulfate-reducing bacteria to anaerobic wastewater treatment. - Journal of Water Resources \& Water Engineering 22(1): 45-49.

[38] Xu, W., Liu, Y., Zeng, G.et al. (2009): Sulfate-reducing bacteria and research progress of $\mathrm{Cr}(\mathrm{VI})$ reduction by sulfate-reducing bacteria. - Microbiology 36(7): 1040-1045.

[39] Zhao, H., Li, A., Wan, B. et al. (1995): Isolation and physiology of a moderate halophilic sulfate-reducing bacterium. - Chinese Journal of Applied \& Environmental Biology 1(1): 61-67.

[40] Zhao, Y., Ye, Y., Liu, X. (1997): sulfate reducing bacteria and its influencing factors. Journal of Environmental Pollution \& Control 19(5): 41-43.

[41] Zhou, R., Zhao, Y., Zhu, Z. et al. (2008): Redox zones and its functional bacteria in a contaminated landfill site. - Journal of Environmental Science (11): 3270-3274. 